\title{
Assessment Of Beneficiation Routes Of Tantalite Ores From Key Locations In Nigeria
}

\author{
${ }^{1}$ Adetunji, A. R $^{*}{ }^{2}$ Siyanbola, W.O.; ${ }^{3}$ Funtua, I. I; \\ ${ }^{1}$ Olusunle, S. O. O.; ${ }^{1}$ Afonja A.A and ${ }^{1}$ Adewoye, O.O. \\ ${ }^{1}$ Metallurgical and Materials Engineering Department, Obafemi Awolowo University, Ile-Ife \\ ${ }^{2}$ Centre for Energy Research and Development, Obafemi Awolowo University, Ile-Ife \\ ${ }^{3}$ Centre for Energy Research and Training, Ahmadu Bello University, Zaria \\ *Correspondence Author; e-mail: aadetunj@oauife.edu.ng or aderade2004@yahoo.com
}

\begin{abstract}
:
The beneficiation methods for some tantalite ores from selected deposits in Nigeria have been assessed through mineralogical and compositional analyses of the ores. Tantalite ores obtained from eight different well-known locations of the mineral in the country were analyzed with ${ }^{109} \mathrm{Cd}$ excitation source Energy Dispersive X-ray spectrometry using the emission-transmission method of quantification. The major minerals detected and quantified include $\mathrm{TiO}_{2}, \mathrm{MnO}, \mathrm{Fe}_{2} \mathrm{O}_{3}, \mathrm{Ta}_{2} \mathrm{O}_{5}, \mathrm{Nb}_{2} \mathrm{O}_{5}, \mathrm{WO}_{3}$, Th and $\mathrm{U}$. Impurity elements such as $\mathrm{Hf}, \mathrm{Zn}, \mathrm{Zr}, \mathrm{Co}, \mathrm{Pb}, \mathrm{Rb}$, and $\mathrm{Y}$ were also observed and evaluated. Our analyses further show that $\mathrm{Ta}_{2} \mathrm{O}_{5}$ in the ores ranged from a minimum concentration of about $8 \%$ in Otu to about $60 \%$ in the Egbe deposits, while the $\mathrm{Nb}_{2} \mathrm{O}_{5}$ concentrations in the ores ranged from about $20 \%$ to $37.5 \%$ with the highest coming from the Ofiki deposit. Based on these results and the work of other authors, we deduced that clean-up operations might be adequate for Ta extraction from most of the tantalite deposits in Nigeria. The consideration of simplicity and cost of process favours the direct dissolution of the ores in HF for the clean-up operations.
\end{abstract}

Keywords: Tantalite ores, Elemental Composition, EDXRF

\section{INTRODUCTION}

Nigeria is blessed with abundant mineral resources. These include vast deposits of coal, cassiterite, columbite, marble, limestone, clay, bitumen and tantalite. While some of these $m$ inerals are currently $m$ ined, several others have been identified to have huge potentials of being exploited in com mercial scale. The Federal Governm ent of Nigeria is paying renewed attention to the solid $m$ ineral sector; therefore, development activities in the sub-sector are expected to increase many-fold. Recent studies conducted by the Raw Materials Research and Developm ent Council (RMRDC) have show $\mathrm{n}$ that the need to develop capacity for processing of these $\mathrm{m}$ inerals into interm ediate products is the $\mathrm{m}$ ost important requirement of the solid mineral sector in the country [1].

The recovery of tantalite in Nigeria dates back to the 1940's as a by-product of cassiterite mining $[2,3]$. Later, large $t$ onnages of granite c ontaining about $0.26 \% \mathrm{Nb}_{2} \mathrm{O}_{5}$ in urania pyrochlore $\left(3.1 \% \mathrm{U} \quad{ }_{3} \mathrm{O}_{8}, 3.3 \% \mathrm{ThO}_{2}, 37.5 \% \mathrm{Nb}_{2} \mathrm{O}_{5}\right.$ and $\left.3.5 \% \mathrm{Ta}_{2} \mathrm{O}_{5}\right)$ were 
identified. The reserves were however not confirmed. Primary deposits of huge economic value of the ore have now been reported in va rious parts of the country $[4,5,6]$. Indeed, Nigeria is currently rated to be the $7^{\text {th }}$ largest producer of tantalum resources in the world [7]. The production in 2004 was estimated at 25 metric tons.

Tantalite is the most important mineral form of tantalum, a specialty $m$ etal used mainly in the electronics industry for the $m$ anufacture of capacitors and in several specialty alloy applications. The beneficiation of tantalite ores usually involves preconcentration, primary concentration and con centrate clean up. The choice of any or all of these processes would depend on the nature of the ore, $\mathrm{p}$ articularly the conten $\mathrm{t}$ of $\mathrm{Ta}_{2} \mathrm{O}_{5}$ in the $\mathrm{o} \quad \mathrm{re} \mathrm{r}$ elative to its as sociated $\mathrm{m}$ inerals a nd im purities. Typica lly, mechanically mined ores contain less than $0.1 \% \mathrm{Ta}{ }_{2} \mathrm{O}_{5}$, and would ther efore essentially require enrichment through the three processes stated above. The concentration processes may be carried out by wet gravity, $\mathrm{m}$ agnetic or electrostatic $\mathrm{m}$ ethods or by flotation to produce concentrates containing up to $70 \%$ com bined $\mathrm{Ta}_{2} \mathrm{O}_{5}$ and $\mathrm{Nb}{ }_{2} \mathrm{O}_{5}$ to $\mathrm{m}$ eet extraction requirem ents. However, th e universally em ployed $\mathrm{m}$ ethod for the concentration of tantalite ores is $\mathrm{g}$ ravity separation - the separation of two or $\mathrm{m}$ ore minerals as a result of differences in speci fic gravity and their $m$ ovement in response to the force of gravity and one or $m$ ore other forces $[8,9]$. Other $m$ ethods, when used, are employed in the final cleanup of gravity concentrates.

Furthermore, Burt [10] had noted that c oncentrates suitable for further processing to recover Ta are generally required to ex ceed $25 \% \mathrm{Ta}_{2} \mathrm{O}_{5}$, with $50 \%$ combined $\mathrm{Ta}_{2} \mathrm{O}_{5}$ and $\mathrm{Nb}_{2} \mathrm{O}_{5}$. Primary ores with the se $\mathrm{Ta}_{2} \mathrm{O}_{5}$ and $\mathrm{Nb}_{2} \mathrm{O}_{5}$ contents would only need clean-up operations for Ta extraction processes. The clean-up operation results in the rem oval of associated $\mathrm{m}$ inerals and im purity elem ents to a to lerable ex tent. Typica 1 assoc iated minerals include zircon, rutile, $\mathrm{m}$ onazite, cassiterite, ilm enite, garnet, uranium and thorium m inerals, beryl, spodum ene, tourm aline and, in som e cases, aquam arines and gold: light $\mathrm{m}$ inerals such as quartz and feld spar $\mathrm{m}$ ay also be present due to inefficient primary concentration.

A number of reports $[11,12]$ have give $n$ the mineralogical composition of $\mathrm{Ta}-\mathrm{Nb}$ ores obtained from a few locations in the $\mathrm{m}$ iddle belt region of $\mathrm{Ni}$ geria. However, the limitation of these previous wo rks is the failure to relate the results to an upgrading process for a value-added Nigerian tantalite.

The main objective of this work is to assess the appropriate beneficiation schemes by identifying the as sociated elem ents and im purity elem ents in sam ples obtain ed from notable tantalite deposits across Nigeria. The associated elements are known to contribute to the physical characteristics of the Ta $\mathrm{m}$ ineral and thes e characteristics dictate the beneficiation methods. The outcom e of the wo rk reported here would therefore provide critical information about the appropriate $r$ outes for the beneficiation processes needed for value addition to the Nigerian tantalum industry. 


\section{MATERIALS AND METHODS}

Eight sam ples were collected from differe nt notable deposits in Nigeria. The sources are Egbe, Komu, Nassarawa, Agunrege, Baba Ode, Ofiki, Igbo Ijaye and Otu. Six of the locations a re in Oyo Sta te in the S outh Western Nigeria; one location is in Kogi State while one is in Nassarawa State, both deposits located within the middle belt region of the country. The sam ples were obtained from miners in the study areas. The $\mathrm{m}$ iners employ manual methods of mining, in which the samples would have been upgraded to some extent by hand sorting. Measurem ents of the major constituents and trace elem ents were carried out using a ra dioisotope source Energy Disp ersive X-Ray Fluorescence (EDXRF) Spectrometer at the Centre for Energy Research and Training, Ahm adu Bello University, Zaria, Nigeria.

The samples were ground $\mathrm{m}$ anually to powder with an agate $\mathrm{m}$ ortar and pestle to grain size of less than $125 \mu \mathrm{m}$. Pellets of $19 \mathrm{~mm}$ diameter were prepared from $0.3-0.5 \mathrm{~g}$ powder mixed with three drops of organic liquid binder and then pressed at 10 tons with a hydraulic press. Measurem ents were perform ed using an annular $25 \mathrm{~m} \mathrm{Ci}{ }^{109} \mathrm{Cd}$ as the excitation source, which em its Ag-K X-rays $(22.1 \mathrm{keV})$ in which case all elem ents with lower characteristic excitation en ergies were accessible for detection in the samples. The system further consists of a $\mathrm{Si}(\mathrm{Li})$ detect or, with a resolution of $170 \mathrm{eV}$ for the $5.90 \mathrm{keV}$ line, coupled to a com puter controlled ADC -card. Further details about the system have been given elsewhere $[11,13,14]$.

Quantitative analy sis of the $\mathrm{s}$ amples was carr ied out us ing th e Em issionTransmission (E-T) $\mathrm{m}$ ethod, for which a num ber of quantification $\mathrm{m}$ ethods has been developed and applied [13-18]. These quantification $\mathrm{m}$ ethods provide different approaches to correct the matrix absorption as well as enhancem ent effects. In this work quantification was carried ou $\mathrm{t}$ using a $\mathrm{m}$ odified versi on of $\mathrm{E}-\mathrm{T} \mathrm{m}$ ethod $[11,19,20]$, which involves the use of pure target $\mathrm{m}$ aterial (Mo) to $\mathrm{m}$ easure the absorption factors in the sam ple. The Mo target serves as a source of $m$ onochromatic X-rays, which are excited through the sample by prim ary radiation and then penetrate the sam ple on the way to the de tector. In this way, the abso rption factor is experim entally determined. The program then uses th is factor in the quantification of con centration of the elem ents. In addition, the contribution to the Mo-K peak in tensity by the $\mathrm{Zr}-\mathrm{K}$ is subtracted for each sample. The spectra for the sam ples were collected for $3000 \mathrm{~s}$ with the ${ }^{109} \mathrm{Cd}$ and the spectra were then evaluated using the AXIL- QXAS program [21]. It was noted that very light mineral associations of the Ta ores could not be determined due to the absence of an ${ }^{55} \mathrm{Fe}$ excitation source.

\section{RESULTS AND DISCUSSION}

The results of the $m$ ineralogical analys is including a num ber of impurities/trace elements are shown in Tab le 1. The results show tha $t$ the Egb e sam ple contain $s$ the highest $\mathrm{Ta}_{2} \mathrm{O}_{5}$ content at 59.58\%. The Ta ${ }_{2} \mathrm{O}_{5}$ contents of Kom u, Nassarawa, Agunrege, 
Baba Ode, Ofiki, Igbo Ijaye and Otu ore sam ples are respectively $49.57 \%, 46.15 \%$, $45.42 \%, 42.00 \%, 36.63 \%, 23.64 \%$ and $8.00 \%$. The resu $\quad$ lts further showed that the samples also contain appreciable am ounts of $\mathrm{Nb}_{2} \mathrm{O}_{5}$ and $\mathrm{TiO}_{2}$. Other mineral ores/phases identified and quantified include $\mathrm{MnO}, \mathrm{Fe}_{2} \mathrm{O}_{3}, \mathrm{WO}_{3}$, Th and $\mathrm{U}$. Impurities/trace elements such as $\mathrm{Hf}, \mathrm{Zn}, \mathrm{Zr}, \mathrm{Co}, \mathrm{Pb}, \mathrm{Rb}$, and $\mathrm{Y}$ were also determined.

Table 1: Mineralogical Analysis of Tantalum Ore Samples From 8 Different Locations in Nigeria.

\begin{tabular}{|c|c|c|c|c|c|c|c|c|}
\hline Oxide & Egbe & Komu & $\begin{array}{l}\text { Nassara } \\
\text { wa }\end{array}$ & $\begin{array}{l}\text { Agunreg } \\
\text { e }\end{array}$ & $\begin{array}{l}\text { Baba } \\
\text { Ode }\end{array}$ & Ofiki & $\begin{array}{l}\text { Igbo } \\
\text { Ijaye }\end{array}$ & Otu \\
\hline $\mathrm{TiO}_{2} \%$ & - & - & $\begin{array}{l}3.81 \\
\pm 0.42\end{array}$ & $\begin{array}{l}1.64 \\
\pm 0.37\end{array}$ & $\begin{array}{l}2.34 \\
\pm 0.42\end{array}$ & $\begin{array}{l}1.05 \\
\pm 0.33\end{array}$ & $\begin{array}{l}20.36 \\
\pm 0.58\end{array}$ & $\begin{array}{l}33.38 \\
\pm 0.67\end{array}$ \\
\hline $\mathrm{MnO} \%$ & $\begin{array}{l}4.15 \\
\pm 0.10\end{array}$ & $\begin{array}{l}9.03 \\
\pm 0.17\end{array}$ & $\begin{array}{l}5.80 \\
\pm 0.13\end{array}$ & $\begin{array}{l}6.69 \\
\pm 0.14\end{array}$ & $\begin{array}{l}8.62 \\
\pm 0.17\end{array}$ & $\begin{array}{l}10.10 \\
\pm 0.18\end{array}$ & $\begin{array}{l}3.46 \\
\pm 0.12\end{array}$ & $\begin{array}{l}0.74 \\
\pm 0.09\end{array}$ \\
\hline $\mathrm{Fe}_{2} \mathrm{O}_{3} \%$ & $\begin{array}{l}7.76 \\
\pm 0.18\end{array}$ & $\begin{array}{l}3.51 \\
\pm 0.14\end{array}$ & $\begin{array}{l}10.69 \\
\pm 0.23\end{array}$ & $\begin{array}{l}7.37 \\
\pm 0.18\end{array}$ & $\begin{array}{l}4.69 \\
\pm 0.16\end{array}$ & $\begin{array}{l}2.86 \\
\pm 0.13\end{array}$ & $\begin{array}{l}9.66 \\
\pm 0.21\end{array}$ & $\begin{array}{l}9.70 \\
\pm 0.20\end{array}$ \\
\hline $\mathrm{Ta}_{2} \mathrm{O}_{5} \%$ & $\begin{array}{l}59.58 \\
\pm 0.62\end{array}$ & $\begin{array}{l}49.57 \\
\pm 0.54\end{array}$ & $\begin{array}{l}46.15 \\
\pm 0.52\end{array}$ & $\begin{array}{l}45.42 \\
\pm 0.49\end{array}$ & $\begin{array}{l}42.00 \\
\pm 0.46\end{array}$ & $\begin{array}{l}36.63 \\
\pm 0.42\end{array}$ & $\begin{array}{l}23.64 \\
\pm 0.40\end{array}$ & $\begin{array}{l}8.00 \\
\pm 0.17\end{array}$ \\
\hline $\mathrm{Nb}_{2} \mathrm{O}_{5} \%$ & $\begin{array}{l}19.74 \\
\pm 0.17\end{array}$ & $\begin{array}{l}29.18 \\
\pm 0.23\end{array}$ & $\begin{array}{l}24.86 \\
\pm 0.20\end{array}$ & $\begin{array}{l}31.18 \\
\pm 0.26\end{array}$ & $\begin{array}{l}32.90 \\
\pm 0.26\end{array}$ & $\begin{array}{l}37.48 \\
\pm 0.29\end{array}$ & $\begin{array}{l}28.90 \\
\pm 0.29\end{array}$ & $\begin{array}{l}22.43 \\
\pm 0.17\end{array}$ \\
\hline $\mathrm{WO}_{3} \%$ & - & $\begin{array}{l}0.38 \\
\pm 0.13\end{array}$ & $\begin{array}{l}1.80 \\
\pm 0.14\end{array}$ & - & - & - & $\begin{array}{l}0.32 \\
\pm 0.09\end{array}$ & $\begin{array}{l}0.17 \\
\pm 0.05\end{array}$ \\
\hline $\mathrm{SnO}_{2} \%$ & - & - & $\begin{array}{l}8.43 \\
\pm 1.97\end{array}$ & - & - & - & - & - \\
\hline $\mathrm{Hf} \%$ & $\begin{array}{l}0.22 \\
\pm 0.05\end{array}$ & $\begin{array}{l}0.26 \\
\pm 0.05\end{array}$ & $\begin{array}{l}0.31 \\
\pm 0.05\end{array}$ & $\begin{array}{l}0.18 \\
\pm 0.05\end{array}$ & $\begin{array}{l}0.17 \\
\pm 0.05\end{array}$ & $\begin{array}{l}0.11 \\
\pm 0.04\end{array}$ & $\begin{array}{l}0.13 \\
\pm 0.04\end{array}$ & - \\
\hline $\mathrm{Zn} \%$ & - & $\begin{array}{l}0.22 \\
\pm 0.03\end{array}$ & $\begin{array}{l}0.09 \\
\pm 0.03\end{array}$ & - & $\begin{array}{l}0.09 \\
\pm 0.03\end{array}$ & $\begin{array}{l}0.07 \\
\pm 0.02\end{array}$ & - & - \\
\hline $\mathrm{Zr} \%$ & $\begin{array}{l}0.31 \\
\pm 0.01\end{array}$ & $\begin{array}{l}0.12 \\
\pm 0.01\end{array}$ & $\begin{array}{l}0.26 \\
\pm 0.01\end{array}$ & $\begin{array}{l}0.15 \\
\pm 0.01\end{array}$ & $\begin{array}{l}0.22 \\
\pm 0.01\end{array}$ & $\begin{array}{l}0.17 \\
\pm 0.01\end{array}$ & $\begin{array}{l}0.06 \\
\pm 0.01\end{array}$ & $\begin{array}{l}0.06 \\
\pm 0.01\end{array}$ \\
\hline $\mathrm{Pb}(\mathrm{ppm})$ & $\begin{array}{l}489 \\
\pm 146\end{array}$ & $\begin{array}{l}570 \\
\pm 146\end{array}$ & $\begin{array}{l}1720 \\
\pm 195\end{array}$ & - & $\begin{array}{l}1010 \\
\pm 168\end{array}$ & $\begin{array}{l}720 \\
\pm 146\end{array}$ & - & - \\
\hline Rb ppm) & - & $120 \pm 47$ & - & - & - & - & - & - \\
\hline $\mathrm{Y}$ ppm) & $t$ & - & $333 \pm 51$ & - & - & - & - & - \\
\hline $\mathrm{ThO}_{2} \%$ & 0.34 & 0.03 & 0.15 & 0.02 & 0.02 & 0.05 & 0.03 & 0.01 \\
\hline $\mathrm{U}_{3} \mathrm{O}_{8} \%$ & 0.17 & 0.37 & 0.65 & 0.42 & 0.94 & 1.57 & 0.28 & 0.27 \\
\hline
\end{tabular}

The elem ental Ta content in the respective ore sam ples are $48.79 \%, 40.59 \%$, $37.79 \%, 37.19 \%, 34.39 \%, 30 \%, 19.36 \%$ and $6.55 \% \quad$ respectively for Egbe, Kom u, Nassarawa, Agunrege Baba Ode, Ofiki, Igbo Ijaye and Otu. An earlier work by Funtua [11] put the Ta content in the central pegmatite region around Jos, Nassarawa and Jama'a areas of central Nigeria at between 21 and about 30\%. We note that this figure is somehow less than the Nassarawa ore found to be about $38 \%$ in the current investigation. The difference could probably be explained in term $\mathrm{s}$ of the diversity in the ore contents from site to site and from ore vein to ore vein.

In terms of beneficiation, the density of $\mathrm{Ta}-\mathrm{Nb}$ minerals allows concentration with other heavy minerals by gravity methods; sluices, jigs, spirals and shaking tables are used in conjunction with screen sizing; other proc esses, when used, are em ployed in the final cleanup of gravity concentrates. Ta-Nb is combination of high-tension electrostatic separated from other heavy $m$ inerals by a and high-intensity electrom agnetic m eans. 
Concentrates from Nigerian placer deposits, which ar e worked pr imarily for cass iterite, are dried and treated by $\mathrm{m}$ agnetic separators to $\mathrm{r}$ emove the $\mathrm{m}$ agnetic cons tituents: magnetite, ilmenite, columbite, monazite and magnetic cassiterite. The magnetic fraction is then re- treated to sepa rate the $\mathrm{d}$ ifferent minerals. Columbite, monazite and $\mathrm{m}$ agnetic cassiterite are weak ly magnetic. Columbite and magnetic cassiterite are separated on air flotation tables, whereas colum bite and $\mathrm{m}$ onazite are $\mathrm{s}$ eparated e lectrostatically [2]. Classification, screening, and deslim ing ar e em ployed as adjuncts, depending on the composition of the ore. Treatment schemes vary from the most primitive hand methods to extremely com plex modern plants [22]. The liberation of values from waste $\mathrm{m}$ ust be carried out with care, since all tantalum minerals are friable, and, ac cording to Burt [10], concentration efficiency decreases with decreasing particle size.

Gravity p lant con centrate, grad ing approx imately $25 \% \mathrm{Ta} \quad{ }_{2} \mathrm{O}_{5}$ is g enerally upgraded to $50 \%$ in a clean-up plant. The $\mathrm{Nb}$ content in the ore is very im portant. Concentrates suitable for further processi $\mathrm{ng}$ to recover $\mathrm{Ta}$ are generally required to exceed $25 \% \mathrm{Ta}_{2} \mathrm{O}_{5}$, with $50 \%$ combined $\mathrm{Ta}_{2} \mathrm{O}_{5}$ and $\mathrm{Nb}_{2} \mathrm{O}_{5}$ [10]. The ores below this level of $\mathrm{Ta}_{2} \mathrm{O}_{5}-\mathrm{Nb}_{2} \mathrm{O}_{5}$ content need to be enriched by methods discussed above. The tantalum ores from Egbe, Komu, Nassarawa, Agunr ege, Baba Ode and Ofiki all have Ta ${ }_{2} \mathrm{O}_{5}$ $\mathrm{Nb}_{2} \mathrm{O}_{5}$ combined content of about $70 \%$, w ith the $\mathrm{Ta}_{2} \mathrm{O}_{5}$ contents of over $25 \%$. Thus these ores can be subjected directly to clean- up operations, without pre-concentration or primary concentration, for the rem oval of a ssociated minerals. Many of the ores $m$ ay even be subjected to direct hydrom etallurgical extraction processes without going through clean-up operations. This is because their $\mathrm{Ta}_{2} \mathrm{O}_{5}$ contents fall into categories for which technologies have specifically been developed as raw materials of different origins and grades [23], as shown in Table 2. The ore sample from Igbo Ijaye, which contains $23.64 \% \mathrm{Ta}_{2} \mathrm{O}_{5}$, is rich enough for prim ary concentration, while the Otu ore sam ple, with $8 \% \mathrm{Ta}_{2} \mathrm{O}_{5}$, would be enriched right from the pre-concentration stage (Table 3). Thes e two ore samples were however found to have a high $\mathrm{T} \quad \mathrm{iO}_{2}$ content of $20.36 \%$ and $33.38 \%$ respectively. Although the Otu figure is lower than that of a recently studied rutile sample [24], it would be appropriate to treat the ore pr imarily for rutile $r$ ecovery and then secondary recovery for tantalite and niobite.

Table 2: Correlation between technology and raw material input [23]

\begin{tabular}{|c|c|c|}
\hline Technology & Raw Material Input & $\% \mathrm{Ta} / \mathrm{Ta}_{2} \mathrm{O}_{5}$ \\
\hline Pyrometallurgy & Low - Medium Grade Tin Slags & $2-10 \% \mathrm{Ta}_{2} \mathrm{O}_{5}$ \\
\hline Chlorination & Alloys, Scraps & $40-100 \% \mathrm{Ta}$ \\
\hline Hydrometallurgy & Natural Ores & $20-40 \% \mathrm{Ta}_{2} \mathrm{O}_{5}$ \\
& Synthetic Concentrates & $20-40 \% \mathrm{Ta}_{2} \mathrm{O}_{5}$ \\
& High Grade Tin Slags & $>15 \% \mathrm{Ta}_{2} \mathrm{O}_{5}$ \\
\hline
\end{tabular}

The main associations of $\mathrm{Ta}_{2} \mathrm{O}_{5}$ in the ores und er investigation apart from $\mathrm{Nb}_{2} \mathrm{O}_{5}$ and rutile are hematite, wolframite, uranium, cassiterite minerals as well as hafnium, zinc and zirconium elements with other trac e elements. We note that because $\mathrm{T}_{\mathrm{iO}}$ and $\mathrm{MnO}$ are param agnetic and $\mathrm{Fe}{ }_{2} \mathrm{O}_{3}$ is ferrom agnetic, they can be separated from the ore by magnetic separation, whereas electrostati c separation can be em ployed to rem ove cassiterite, hem atite, ilm enite, tan talite, $n$ iobite and wolf ramite, which a re e lectrically 
conducting, from the ore, leaving the non- conducting zirconium com pounds in the gangue. An earlier work by our group [25] had not been able to present the data shown in this work on th e im purity/trace e lement conten ts of the o res. Mo st of thes e elem ents would go into the gangue during the elimination of the major constituents by the physical and subsequent chemical methods.

Table 3: Recommended beneficiation routes for different grades of $\mathrm{Ta}_{2} \mathrm{O}_{5}$ ores (Adapted from table provided by Burt, [10])

\begin{tabular}{|l|l|l|}
\hline $\mathrm{Ta}_{2} \mathrm{O}_{5}$ Content (\%) & Sample Sources Content $\left(\% \mathrm{Ta}_{2} \mathrm{O}_{5}\right)$ & Beneficiation Route \\
\hline$<10$ & Out (8.00) & $\begin{array}{l}\text { Preconcentration (sizing, gravity } \\
\text { separation }\end{array}$ \\
\hline $10-25$ & Igbo Ijaye (23.64) & $\begin{array}{l}\text { Primary concentration (jigs and sluices) } \\
\text { Hydraulic classification } \\
\text { Stage treatment (spirals, shaking tables) }\end{array}$ \\
\hline$>25$ & $\begin{array}{l}\text { Egbe (59.58), Komu (49.57, } \\
\text { Nassarawa (46.15), Agunrege } \\
(45.42), \text { Baba Ode (42.00), Ofiki } \\
(36.63)\end{array}$ & $\begin{array}{l}\text { Concentrate clean-up (floatation, } \\
\text { leaching, magnetic or electrostatic } \\
\text { separation) }\end{array}$ \\
\hline
\end{tabular}

We note further that based on the characteristics of the ores analysed in this study, a prelim inary tre atment $\mathrm{f}$ or the samples would be fusion with $\mathrm{K} \quad{ }_{2} \mathrm{CO}_{3}$, which would separate $\mathrm{Sn}, \mathrm{Fe}, \mathrm{Mn}$ and $\mathrm{TiO}_{2}$ from the earth acid s [26]. The approach in this ca se, is to fuse at red heat with threefold excess of $\mathrm{K}_{2} \mathrm{CO}_{3}$, dissolve the fused mass in water, filter, then precipitate the tantalum and niobium as the sodium salts. However, the num ber of steps and am ount of reagents required could make this process expensive. Gustion and Pilloton [26] observed that direct dissolution of ores in HF as a clean-up operation would not always produce adequate solution for separation by crystallization or liquid extraction. Thus an alternative route to eff ect a rough purification is to fuse them with caustic. The fused $\mathrm{m}$ ass would then be leached with water to rem ove excess c austic, $\mathrm{Sn}$ and $\mathrm{W}$. The Ta and $\mathrm{Nb}$, in the form of complex tantalates and niobates, are insoluble. An acid leach would then dissolve Fe, Mn, Alkalies, and alkaline earths, leaving as a res idue a $m$ ixture of the acids, $\mathrm{T}$ i, and traces of other contam inants. However, Gustion and Pilloton [26] showed that six add itional op erations must be added to those required by direct HF dissolution in order to accomplish this. These are caustic fusion, crushing of the fusion mass, water leach, filtration of water-leach liquor, acid leach and filtration of acidleach liquor. The caustic fusion step is a hi gh-labour operation. Furth ermore, the labou r requirements for each filtration step are about the same as for direct dis solution, so that filtration co sts rise $100-200 \%$ ov er the dir ect d issolution op eration. Leaching in water requires about $50 \%$ as $\mathrm{m}$ uch labour as direct $\mathrm{d}$ issolution, but since leach ing in acid is comparable to direct $d$ issolution the wet processing of the upgra ded ores altogether requires about $100-150 \% \mathrm{~m}$ ore labour than a direct dissolu tion operation. The consideration of simplicity and cost of proc ess therefore favours the direct dissolution of the ores in $\mathrm{HF}$ to dissolve $\mathrm{Ta}, \mathrm{Nb}, \mathrm{Fe}, \mathrm{Ti}, \quad \mathrm{Mn}$ and $\mathrm{W}$. In practice, the adv antages and disadvantages of caus tic fusion $\mathrm{p}$ rior to th e HF leach $\mathrm{m}$ ust be carefully evaluated. The decision to use caustic fusion depends mainly on the type of ore that is treated and on the method of separation used. If chem ical a nd equilibria data were available for the 
dissolution process, it $\mathrm{m}$ ight be possible to $\mathrm{m}$ aximize $\mathrm{Ta}$ and $\mathrm{Nb}$ dissolution with minimum dissolution of the gangue material.

Finally, it is appropriate to $m$ ention here that depending on the country or region of exportation, som e $\mathrm{Ta} / \mathrm{Nb}$ m inerals cannot be shipped out of thei $r$ country of origin because of their levels of radioactiv ity. The limits of allowed uranium and thorium oxide contents are $0.1 \% \mathrm{U}_{3} \mathrm{O}_{8}$ and $0.1 \% \mathrm{ThO}_{2}$ [27]. All the ore sam ples under investigation would not pass through such trans portation regulation for their $\mathrm{U}_{3} \mathrm{O}_{8}$ content while Egbe and Nassarawa sam ples would not pa ss through as a result of their ThO ${ }_{2}$ content. This measure in principle could create a market problem for the tantalite ores originating from these Nigerian deposits. Where there are ready buyers because of the strategic importance of the end product, i.e. the tantalum metal/compounds, the crude ore is substantially reduced in value because of their radioactive contents. However, Krismer and Hoppe [28] have developed a process for the recovery of the non-radioactive $m$ etal compounds from the ores containing com plexes of $U$ and $T h$. The gangue can now be treated to recover uranium as an additional economic by-product [29].

\section{CONCLUSION}

The analysis of the tantalum ores from ei ght different notable deposits in Nigeria using EDXRF spectrom etry has shown that the Nigerian tantalum ores are of relatively high quality and can therefore be subjected to direct pr ocessing for tantalum products without the need for com plex and costly pr econcentration procedures. The consideration of simplicity and cost of process favours the direct dissolution of the ores in HF. The simultaneous evaluation of rutile and niobium in the ores allows for the assessment of the suitability of the ores for prim ary/secondary recovery processes of rutile and niobium products. In addition, the XRF technique offers the possibility of determining other major constituents such as Fe, Mn, W , Th, U, Hf, Zn and Zr. The tantalite $\mathrm{m}$ ineral can be separated from the ore leavi ng the radioactive elem ents in the gangue, the secondary recovery of which is an added econom ic advantage. The knowledge of the presence of $\mathrm{Co}, \mathrm{Pb}, \mathrm{Rb}$, and $\mathrm{Y}$, as well as radioactive elements in the $\mathrm{s}$ amples would assis $\mathrm{t}$ in evaluating co-dissolved species as well as the development of appropriate beneficiation routes for value-addition to the mineral in Nigeria.

\section{ACKNOWLEDGEMENTS}

The authors appreciate th e support of the Engineeri ng Materials Developm ent Institute, Akure, Nigeria for the part-sponsorship of this work. We are also grateful to the Centre for Energy Research and Training, Ahmadu Bello University, Zaria, whose facilities have been used in carrying out our analyses. 


\section{REFERENCES}

1. Aliyu, A.; 1996; Potentials of the Soli d Minerals Industry in Nigeria; Raw Materials Research and Development Council, Abuja, Nigeria.

2. Miller, G. L.; 1959; Tantalum and Niobium; Butterworths Scientific Publications, London; 12 .

3. Kock, W . and Paschen, P.; 1989; "Tantalum - Processing, Properties and Applications"; JOM 10, pp33-39.

4. Okunlola, O. A.; 1999; "Specialty Metal Potentials of Nigeria"; Proceedings of the First Mining in Nigeria Conference and Workshop; pp67-90.

5. Saint Simon de, P.; 1999; "Specialty Metals in Nigeria: Potential for W orld Class Deposit; Second "Mining in Nigeria" Conference, Abuja, Nigeria; 15.

6. Ministry of Solid Minerals Developm ent; 2003; "Tantalite and the Rare Earth Metals".

7. Cunningham, L. D.; 2005; "Tantalum "; USGS Mineral commodity Summaries; pp166-167.

8. Burt, R. O.; 1984; "Gravity Concentrat ion Technology"; Elsevier Science BV, Amsterdam, p607.

9. Wills, B. A.: 1992; "Mineral Processing Technology", $5{ }^{\text {th }}$ Ed.; Pergam on Press, p408.

10. Burt, R.; 1996; "Beneficiation of Tantalum Ore - How it is Achieved and Could it be Better?"; Proceedings of $125^{\text {th }}$ TMS Annual Meeting and Exhibition; Anaheim, CA. 17-22

11. Funtua, I. I.; 1999a; "Analysis of Nb-Ta ores by Energy Dispersive X-ray Fluorescence Spectrometry”. J. Trace Microprobe Techniques, 17, 2 (1999a), pp89-195.

12. Obiajunwa, E. I.; 2001; "Analysis of some Nigerian solid mineral ores by energydispersive X-ray fluorescence spectroscopy". Nuclear Instruments and Methods in Physics Research B, 184, pp437-430.

13. Markowicz, A. A; and Van Grieken, R. E.; 1993; "Quantification in XRF analysis of interm ediate th ickness sam ples". In: Van Grieken and Markowicz (eds) Handbook of X-Ray Spectroscopy, Marcel Dekler Inc., New York, 339-358.

14. Bernasconi, G. B; Bam ford, S. A; Dosa n, B; Haselberger, N; Markowicz, A; Mahmoud, A; and Valcovic, V.; 1996; "Appl icability of annular source excited systems in quantitative XRF analysis"; X-ray Spectrom. 23, pp65-70.

15. Leroux, J; and Mahmoud, M.; 1996; "X-ray qua ntitative analysis by an em issiontransmission method"; Anal. Chem., 38, pp76-82.

16. Giauque, R. D; Garrett, R. B; and Goda, L. Y.; 1979; "Determ ination of trace elements in light $\mathrm{e}$ lement $\mathrm{m}$ atrices by X-ray fluorescen ce with incohe rent scattered radiation as an internal standard"; Anal. Chem. 51, pp512-516

17. Markowicz, A. A.; 1979; "A $m$ ethod for co rrection for absorption $m$ atrix effects in sam ples of interm ediate thickne ss in EDXRF analysis"; X-Ray Spectrom., 8, pp14-18.

18. Tang, S. M; Kump, P; Yap, C. T; and Bila 1, M. G.; 1986; "Cal culation of relative fluorescence intensity for annular-sour ce geometry by Monte Carlo m ethod"; $X$ Ray Spectrom., 15, pp289-293. 
19. Angeyo, K. H; Patel, J. P; Mangala, J. M; and Naraya, D. G. S.; 1998; "Optimization of X-ray Fluorescence analys is: an exam ple from Kenya" Appl. Radiat. Isot., 49, pp885-891.

20. Funtua I. I.; 1999b; "Application of the transmission-emission method in EDXRF for the dete rmination of trace elements in geological and biological materials"; $J$ Trace Microprobe Techniques; 17, 3, pp293-297.

21. Bernasconi, G. B.; 1996; “AXIL-QXAS”, Instruction Manual, IAEA, Vienna.

22. Warde, J. M., Mee, V. A. and Spedde n, H. R.; 1963; "Colum bium and Tantalum Minerals, Ores, and Ore Preparation"; In: Columbium and Tantalum; Scisco, F. T. and Epremian, E. (eds.); John Wiley \& Sons, p17

23. Eckert, J; 1996; "The Industrial Applicat ion of Pyrom etallurgical, Chlorination and Hydrometallurgy for Producing Tantalum Compounds"; Proceedings of $125^{\text {th }}$ TMS Annual Meeting and Exhibition; Anaheim, CA. pp55-61.

24. Siyanbola, W. O, Fasasi, A. Y, Funtua, I. I, Afolabi, O. M, Adesiyan, T. A and Adetunji, A. R.; 2004; "Elem ental Com position of Rutile From South-W estern Nigeria Using X-Ray Techniques"; Nuclear Instruments and Methods in Physics Research B 215, pp240-245.

25. Adetunji, A. R, Siyanbola, W . O, Funtua, I. I, Afonja, A. A and Adewoye, O. O: 2004; "Energy Dispersive X- Ray Fluorescence Analysis of Tantalite Ores From Various Deposits in Nigeria"; In: Proceedings of the Nigerian Materials Congress (NIMACON) 2003; Eds: B. Babatope and W . O. Siyanbola; Materials Society of Nigeria; pp38-42.

26. Gustion, R. A. and Pillo ton, R. L. ; 1963; "Extraction and Sep aration of Columbium and Tantalum "; In: Columbium and Tantalum; Sc isco, F. T. and Epremian, E. (eds.); John Wiley \& Sons, pp17.

27. Simandl, G. J.; 2001; “Tantalum Mark et and Resources: An Overview”; Geological Fieldwork; British Colum bia Geol ogical Survey; paper 2002-1, pp313-318.

28. Krismer, B. and Hoppe, A.; 1984; US Patent No 4446116

29. Funtua, I. I, Ogunleye, P. O, Um ar, I. M. and Elegba, S. B.; 1998; "Prelim inary Studies on the Recovery of Uranium From Mika, Northeastern Nigeria"; Journal of Mining and Geology, vol 34, No 2, pp219-224 